\title{
Factors influencing business activities for export development
}

\author{
Maryam Baheri*, Valiollah Berangi Taleghani and Parviz Nasiri
}

Department of Management and Accounting, South Branch, Islamic Azad University, Tehran, Iran

\begin{tabular}{l}
\hline C H R O N I C L E \\
\hline Article history: \\
Received April 20, 2015 \\
Received in revised format June \\
10, 2015 \\
Accepted August 202015 \\
Available online \\
August 22 2015 \\
\hline Keywords: \\
Business development \\
Food industry \\
Export development \\
\hline
\end{tabular}
A B S T R A C T

\begin{abstract}
Export is the backbone of business development in any industry and it plays essential role on the success of organizations. The objective of this study is to determine factors influencing on food industry for development of export activities. The study designs a questionnaire in Likert scale and distributes it among 247 randomly selected experts who were active in production of foods in city of Tehran, Iran. Using principle component analysis based on varimax rotation, the study detects six factors including social opportunities, international opportunities, customer orientation, business opportunities, new technologies, organizational capabilities, commercialization of ideas on the development of export markets.
\end{abstract}

(C) 2016 Growing Science Ltd. All rights reserved.

\section{Introduction}

Export is the backbone of business development in any industry and it plays essential role on the success of organizations (Dichtl, 1984). Small companies are believed to contribute 25 to 35\% of world exports of manufacturers, and about one fifth of manufacturing small companies receive $10-40 \%$ of their turnover from cross-border activities (Wolff \& Pett, 2000; Andersson et al. 2004). In addition, small companies appear to get into the international market at a much earlier age than before, and they are also more actively following strategies that involve international activities (Knight \& Cavusgil, 1996; McDougall \& Oviatt, 2000). There are several studies associated with the adaptation of business activates towards boosting export activities.

Mohammadi et al. (2014) determined different factors influencing on development of packaging to have better influence on domestic as well as international market including communications, infrastructure, awareness, design and technical extraction. Nosouzi et al. (2013) performed a study to find out factors influencing on exporting medicinal plants and determined eight factors including environmental issues, export supportive issues, potentials for export, business plan, export plan, structural barriers, competition capability and strategy. Hosseini et al. (2014) performed a study to learn more about the effects of firm and management team's characteristics to develop food industry. They 
reported that "management knowledge about export market was number one important factor followed by the level of technology used, competitive advantage, believe in being profitable”. Nikseresht (2013) discussed how empowering small and mid-cap firms could develop national exports.

Shekari et al. (2011) determined and modeled the drivers of Green supply chain management (GSCM) to put environmental activities into practice. Their results demonstrated that a six-factor measurement model (including internal environmental management, green purchasing, cleaner production, recovery, eco-design and pollution) could fit the data acceptably. Nikfarjam and Zarifi (2015) determined entrepreneurial marketing factors affecting on small and medium enterprises (SMEs), which were active in Iranian food industry. The study has determined five factors including innovative approach, flexible marketing, customer, product strategy and resources, which were influencing the most on entrepreneurial marketing factors.

Cadogan et al. (2002) extended some previous studies associated with market orientation into the international arena by developing and examining hypotheses associated with the antecedents to and consequences of market-oriented activities in companies' export operations. Export experience, export dependence and coordinating capabilities were detected in this study to be positively associated with export market-oriented activities. Moreover, export market-oriented activities were positively related to aspects of export performance.

Leonidou et al. (2002) aimed to synthesize extant knowledge based on a meta-analysis of empirical studies on the export marketing strategy-performance relationship. The study disclosed that although several marketing strategy variables could yield positive effects on overall export performance, the relationship was not always meaningful. In addition, the export performance measures investigated in different studies, stronger effects were observed in association with export proportion of sales. Finally, time of study, geographic focus, and product type had a limited effect on the impact of marketing strategy elements on export performance. According to Haar and Ortiz-Buonafina (1995), the policy adopted by many counties emphasized an increase in the volume of exports with the objective of diversifying export markets and products.

Haar and Ortiz-Buonafina (1995) addressed the process by which Brazilian companies internationalized their manufactured goods. They collected the necessary data from a large sample of companies belonging to the Association of Brazilian Exporters (AEB). They also used factor analysis for the purpose of summarizing the information with regard to export marketing dimensions. Discriminant analysis was implemented to determine the marketing dimensions pertinent to each group at various levels of the internationalization process in export activities. They reported that export development in Brazilian firms was directed by currency issues and marketing capabilities. Moreover, the study disclosed some important insights into the success of export activities.

\section{The proposed study}

The objective of this study is to determine factors influencing on food industry for development of export activities. The study designs a questionnaire in Likert scale and distributes it among 247 randomly selected employees who were active in production of foods in city of Tehran, Iran. Cronbach's alpha based on standardized items has been calculated as 0.809. In addition, Kaiser-MeyerOlkin Measure of Sampling Adequacy yields a Chi-Square value of 2239.59(Sig. = 0.000), which confirm the overall questionnaire of this survey. Table 1 and Table 2 demonstrate the summary of some basic statistics on the survey and total variance, respectively. In addition, Fig. 1 shows the results of Scree plot. Moreover, Table 3 shows the summary of principle component analysis with varimax rotation. 
Table 1

The summary of some basic statistics

\begin{tabular}{|c|c|c|c|c|c|c|c|c|}
\hline & & \multirow[b]{2}{*}{$\begin{array}{c}\mathrm{N} \\
\text { Statistic }\end{array}$} & \multirow[b]{2}{*}{$\begin{array}{l}\text { Minimum } \\
\text { Statistic }\end{array}$} & \multirow[b]{2}{*}{$\begin{array}{l}\text { Maximum } \\
\text { Statistic }\end{array}$} & \multicolumn{2}{|c|}{ Skewness } & \multicolumn{2}{|c|}{ Kurtosis } \\
\hline & & & & & Statistic & $\begin{array}{l}\text { Std. } \\
\text { Error }\end{array}$ & Statistic & $\begin{array}{l}\text { Std. } \\
\text { Error }\end{array}$ \\
\hline 1 & The growing demand for customized products & 247 & 1 & 5 & -0.423 & 0.155 & -0.497 & 0.309 \\
\hline 2 & International opportunity recognition & 247 & 1 & 5 & -0.366 & 0.155 & -0.416 & 0.309 \\
\hline 3 & Regional markets & 247 & 1 & 5 & -0.296 & 0.155 & -0.626 & 0.309 \\
\hline 4 & Product Development Performance & 247 & 1 & 5 & 0.02 & 0.155 & -0.422 & 0.309 \\
\hline 5 & Human Capital & 247 & 1 & 5 & -0.642 & 0.155 & 0.079 & 0.309 \\
\hline 6 & Internet sales & 247 & 1 & 5 & -0.855 & 0.155 & 0.535 & 0.309 \\
\hline 7 & Individual factors & 247 & 1 & 5 & -0.781 & 0.155 & 0.379 & 0.309 \\
\hline 8 & Industry growth rate & 247 & 1 & 5 & -0.393 & 0.155 & -0.264 & 0.309 \\
\hline 9 & Participation in International Exhibitions & 247 & 1 & 5 & -0.474 & 0.155 & -0.432 & 0.309 \\
\hline 10 & Social source & 247 & 1 & 5 & -0.498 & 0.155 & -0.222 & 0.309 \\
\hline 11 & Opportunity Recognition in Social activities & 247 & 1 & 5 & -0.448 & 0.155 & -0.561 & 0.309 \\
\hline 12 & Growth in market share & 247 & 1 & 5 & -0.152 & 0.155 & -0.701 & 0.309 \\
\hline 13 & The support of new ideas & 247 & 1 & 5 & -0.38 & 0.155 & -0.557 & 0.309 \\
\hline 14 & Customer-oriented approach in innovation & 247 & 1 & 5 & -0.419 & 0.155 & -0.519 & 0.309 \\
\hline 15 & Industry interaction with research teams & 247 & 1 & 5 & -0.48 & 0.155 & 0.931 & 0.309 \\
\hline 16 & Ecommerce & 247 & 1 & 5 & -0.363 & 0.155 & -0.255 & 0.309 \\
\hline 17 & Business ideas & 247 & 1 & 5 & 0.118 & 0.155 & -0.946 & 0.309 \\
\hline 18 & Networking & 247 & 1 & 5 & -0.912 & 0.155 & 0.439 & 0.309 \\
\hline 19 & Globalization & 247 & 1 & 5 & -0.337 & 0.155 & -0.485 & 0.309 \\
\hline 20 & Providing subsidies to producers & 247 & 1 & 5 & -0.236 & 0.155 & 0.221 & 0.309 \\
\hline 21 & market prediction & 247 & 1 & 5 & -0.811 & 0.155 & -0.087 & 0.309 \\
\hline 22 & $\mathrm{CE}$ & 247 & 1 & 5 & -0.507 & 0.155 & 1.134 & 0.309 \\
\hline 23 & Tariffs & 247 & 1 & 5 & -0.352 & 0.155 & 0.418 & 0.309 \\
\hline 24 & Government incentives & 247 & 1 & 5 & 0.119 & 0.155 & -1.2 & 0.309 \\
\hline 25 & Organizational capabilities & 247 & 1 & 5 & -0.226 & 0.155 & -0.966 & 0.309 \\
\hline 26 & The idea of market-oriented research & 247 & 1 & 5 & -0.478 & 0.155 & 0.461 & 0.309 \\
\hline 27 & Fashion Market & 247 & 1 & 5 & -0.224 & 0.155 & -0.92 & 0.309 \\
\hline 28 & Technological Innovation & 247 & 1 & 5 & -0.685 & 0.155 & 0.47 & 0.309 \\
\hline 29 & Offer new product ideas & 247 & 1 & 5 & -0.845 & 0.155 & 0.752 & 0.309 \\
\hline 30 & Craft industry & 247 & 1 & 5 & -0.767 & 0.155 & 0.373 & 0.309 \\
\hline 31 & Environmental entrepreneurship & 247 & 1 & 5 & -0.606 & 0.155 & 0.052 & 0.309 \\
\hline 32 & The use of new technologies by the company & 247 & 1 & 5 & -0.276 & 0.155 & -0.511 & 0.309 \\
\hline 33 & Speed commercialization process & 247 & 1 & 5 & -0.824 & 0.155 & 0.204 & 0.309 \\
\hline 34 & Family SMEs & 247 & 1 & 5 & -0.735 & 0.155 & 0.654 & 0.309 \\
\hline
\end{tabular}

Table 2

The summary of total variance

\begin{tabular}{|c|c|c|c|c|c|c|c|c|c|}
\hline \multirow[b]{2}{*}{ Component } & \multicolumn{3}{|c|}{ Initial Eigen values } & \multicolumn{3}{|c|}{ Extraction Sums of Squared Loadings } & \multicolumn{3}{|c|}{ Rotation Sums of Squared Loadings } \\
\hline & Total & $\begin{array}{c}\% \text { of } \\
\text { Variance }\end{array}$ & Cumulative \% & Total & $\begin{array}{c}\text { \% of } \\
\text { Variance }\end{array}$ & Cumulative \% & Total & $\begin{array}{c}\% \text { of } \\
\text { Variance }\end{array}$ & Cumulative \% \\
\hline 1 & 5.435 & 16.469 & 16.469 & 5.435 & 16.469 & 16.469 & 2.955 & 8.956 & 8.956 \\
\hline 2 & 2.581 & 7.822 & 24.291 & 2.581 & 7.822 & 24.291 & 2.798 & 8.479 & 17.435 \\
\hline 3 & 2.189 & 6.633 & 30.924 & 2.189 & 6.633 & 30.924 & 2.257 & 6.84 & 24.275 \\
\hline 4 & 1.796 & 5.442 & 36.366 & 1.796 & 5.442 & 36.366 & 2.072 & 6.279 & 30.554 \\
\hline 5 & 1.649 & 4.998 & 41.363 & 1.649 & 4.998 & 41.363 & 1.952 & 5.916 & 36.47 \\
\hline 6 & 1.4 & 4.243 & 45.606 & 1.4 & 4.243 & 45.606 & 1.732 & 5.248 & 41.718 \\
\hline 7 & 1.33 & 4.03 & 49.636 & 1.33 & 4.03 & 49.636 & 1.596 & 4.836 & 46.554 \\
\hline 8 & 1.278 & 3.871 & 53.508 & 1.278 & 3.871 & 53.508 & 1.593 & 4.827 & 51.381 \\
\hline 9 & 1.159 & 3.512 & 57.02 & 1.159 & 3.512 & 57.02 & 1.43 & 4.334 & 55.715 \\
\hline 10 & 1.075 & 3.258 & 60.278 & 1.075 & 3.258 & 60.278 & 1.283 & 3.888 & 59.603 \\
\hline 11 & 1.008 & 3.054 & 63.332 & 1.008 & 3.054 & 63.332 & 1.23 & 3.729 & 63.332 \\
\hline 12 & 0.935 & 2.832 & 66.164 & & & & & & \\
\hline 13 & 0.901 & 2.73 & 68.894 & & & & & & \\
\hline 14 & 0.807 & 2.447 & 71.341 & & & & & & \\
\hline 15 & 0.757 & 2.295 & 73.636 & & & & & & \\
\hline 16 & 0.714 & 2.164 & 75.799 & & & & & & \\
\hline 17 & 0.7 & 2.12 & 77.919 & & & & & & \\
\hline 18 & 0.676 & 2.048 & 79.967 & & & & & & \\
\hline 19 & 0.622 & 1.884 & 81.851 & & & & & & \\
\hline 20 & 0.595 & 1.803 & 83.654 & & & & & & \\
\hline 21 & 0.567 & 1.72 & 85.373 & & & & & & \\
\hline 22 & 0.55 & 1.666 & 87.039 & & & & & & \\
\hline 23 & 0.539 & 1.634 & 88.673 & & & & & & \\
\hline 24 & 0.514 & 1.559 & 90.231 & & & & & & \\
\hline 25 & 0.473 & 1.434 & 91.665 & & & & & & \\
\hline 26 & 0.431 & 1.306 & 92.971 & & & & & & \\
\hline 27 & 0.417 & 1.262 & 94.233 & & & & & & \\
\hline 28 & 0.375 & 1.137 & 95.37 & & & & & & \\
\hline 29 & 0.361 & 1.093 & 96.463 & & & & & & \\
\hline 30 & 0.328 & 0.992 & 97.456 & & & & & & \\
\hline 31 & 0.305 & 0.925 & 98.381 & & & & & & \\
\hline 32 & 0.281 & 0.851 & 99.232 & & & & & & \\
\hline
\end{tabular}




\section{Table 3}

The summary of principle component analysis after rotation

\begin{tabular}{|c|c|c|c|c|c|c|c|c|c|c|c|}
\hline & \multicolumn{11}{|c|}{ Rotated Component Matrix ${ }^{\mathrm{a}}$} \\
\hline & 1 & 2 & 3 & 4 & 5 & 6 & 7 & 8 & 9 & 10 & 11 \\
\hline q31 & 0.797 & & & & & & & & & & \\
\hline q30 & 0.734 & & & & & & & & & & \\
\hline q11 & 0.664 & & & & & & & & & & \\
\hline $\mathrm{q} 10$ & 0.64 & & & & & & & & & & \\
\hline q34 & 0.572 & & & & & & & & & & \\
\hline q2 & & 0.817 & & & & & & & & & \\
\hline q19 & & 0.812 & & & & & & & & & \\
\hline q3 & & 0.743 & & & & & & & & & \\
\hline q9 & & 0.582 & & & & & 0.436 & & & & \\
\hline q27 & & & 0.792 & & & & & & & & \\
\hline q14 & & & 0.685 & & & & & & & & \\
\hline $\mathrm{q} 1$ & & & 0.655 & & & & & & & & \\
\hline q26 & & & 0.516 & & & & 0.341 & & & & \\
\hline q20 & & & & 0.725 & & & & & & & \\
\hline q35 & & & & 0.704 & & & & & & & \\
\hline $\mathrm{q} 22$ & & & & 0.671 & & & & & & & \\
\hline q15 & & & & 0.651 & & & & & & & \\
\hline q28 & & & & & 0.75 & & & & & & \\
\hline q6 & & & & & 0.558 & & & & & & \\
\hline q16 & 0.435 & & & & 0.55 & & & & & & \\
\hline q32 & & & & & & 0.777 & & & & & \\
\hline q18 & & & & & & 0.675 & & & & & \\
\hline q21 & & & & & 0.407 & 0.407 & & & & & \\
\hline q33 & & & & & & & 0.753 & & & & \\
\hline q29 & & & & & & 0.34 & 0.533 & & & & \\
\hline $\mathrm{q} 13$ & & & & & & & 0.411 & & & & \\
\hline q5 & & & & & & & & 0.721 & & & \\
\hline q8 & & & & & & & & 0.704 & & & \\
\hline $\mathrm{q} 4$ & & & & & & & & & 0.797 & & \\
\hline q24 & & & & & & & & & 0.549 & & -0.415 \\
\hline $\mathrm{q} 12$ & & & & & & & & & & 0.791 & \\
\hline $\mathrm{q} 17$ & & & 0.37 & & 0.386 & & & & & 0.543 & \\
\hline
\end{tabular}

\section{Results, discussion and conclusion}

The implementation of principle component analysis based on varimax rotation, the study detects six factors including social opportunities, international opportunities, customer orientation, business opportunities, new technologies, organizational capabilities, commercialization of ideas on the development of export markets. The first factor, social opportunities, includes environmental entrepreneurship, craft industry, family SMEs, social source and opportunity recognition in social activities. The results of this section are consistent with findings of Leonidou et al. (2002) and Mohammadi et al. (2014).

The second factor, international opportunities, consists of four items including international opportunity recognition, participation in international exhibitions, regional markets and globalization. The results of this part of survey are in line with Holzmüller and Kasper, H. (1991), Karafakioglu (1986) and Nosouzi et al. (2013). The third factor, customer orientation, includes four sub-components including the growing demand for customized products, customer-oriented approach in innovation, the idea of market-oriented research and fashion Market. The findings of this part are consistent with findings of Czinkota and Johnston (1981), Filatotchev et al. (2012) and Hosseini et al. (2014).

The fourth factor, organizational capabilities, includes Industry interaction with research teams, providing subsidies to producers, organizational learning and organizational entrepreneurship. The results of this part are consistent with findings reported by Nikseresht (2013), Katsikeas (1994) and Katsikeas et al. (1996). The fifth factor, business opportunities, includes three items of adaptation of new technologies, building network and market forecasting. The results are consistent with earlier results presented by Hook Jr and Czinkota (1989), Nikseresht (2013) and Hosseini et al. (2014). 
Finally, the last factor, commercialization of ideas, was the last item influencing on development of export activities in food industry, which consists of three sub-item including the support of new ideas, offering new product ideas and the use of new technologies by the company. These results are also consistent with findings reported by Haar and Ortiz-Buonafina (1995), Bennett (1997) and Alimohammadi et al. (2014).

\section{Acknowledgement}

The authors would like to thank the anonymous referees for constructive comments on earlier version of this paper.

\section{References}

Alimohammadi, Y., Aghamousa, R., \& Meshkani, F. (2014). Examining the role of export competitive advantages on export performance. Management Science Letters, 4(4), 621-626.

Andersson, S., Gabrielsson, J., \& Wictor, I. (2004). International activities in small firms: examining factors influencing the internationalization and export growth of small firms. Canadian Journal of Administrative Sciences, 21(1), 22-34.

Bennett, R. (1997). Export marketing and the internet: Experiences of web site use and perceptions of export barriers among UK businesses. International Marketing Review, 14(5), 324-344.

Cadogan, J. W., Diamantopoulos, A., \& Siguaw, J. A. (2002). Export market-oriented activities: their antecedents and performance consequences. Journal of International Business Studies, 33(3), 615626.

Czinkota, M. R., \& Johnston, W. J. (1981). Segmenting US firms for export development. Journal of Business Research, 9(4), 353-365.

Dichtl, E., Leibold, M., Köglmayr, H. G., \& Mueller, S. (1984). The export-decision of small and medium-sized firms: A review. Management International Review, 24(2), 49-60.

Filatotchev, I., Liu, X., Buck, T., \& Wright, M. (2009). The export orientation and export performance of high-technology SMEs in emerging markets: The effects of knowledge transfer by returnee entrepreneurs. Journal of International Business Studies, 40(6), 1005-1021.

Haar, J., \& Ortiz-Buonafina, M. (1995). The internationalization process and marketing activities: The case of Brazilian export firms. Journal of Business Research, 32(2), 175-181.

Hook Jr, R. C., \& Czinkota, M. R. (1989). Export activities and prospects of Hawaiian firms. Asia Pacific International Journal of Marketing, 1(2), 27-35.

Hosseini, S., Hamedani, A., \& Nikbakht, M. (2014). The effect of firm characteristics and the propensity to export decision in food industry.Management Science Letters, 4(6), 1161-1166.

Holzmüller, H. H., \& Kasper, H. (1991). On a theory of export performance: Personal and organizational determinants of export trade activities observed in small and medium-sized firms. MIR: Management International Review, 31, 45-70.

Karafakioglu, M. (1986). Export activities of Turkish manufacturers.International Marketing Review, 3(4), 34-43.

Katsikeas, C. S. (1994). Perceived export problems and export involvement: the case of Greek exporting manufacturers. Journal of Global Marketing, 7(4), 29-58.

Katsikeas, C. S., Piercy, N. F., \& Ioannidis, C. (1996). Determinants of export performance in a European context. European journal of Marketing, 30(6), 6-35.

Knight, G.A. \& Cavusgil, S.T. (1996). The born global firm: A challenge to traditional internationalization theory. Advances in International Marketing, 8, 11-26.

Leonidou, L. C., Katsikeas, C. S., \& Samiee, S. (2002). Marketing strategy determinants of export performance: a meta-analysis. Journal of Business research, 55(1), 51-67.

McDougall, P.P. \& Oviatt, B.M. (2000). International entrepreneurship: The intersection of two research paths. Academy of Management Journal, 43 (5), 902-906.

Mohammadi, M., Hnzayy, S., \& Azad, N. (2014). A study on packaging factors influencing on export development. Management Science Letters, 4(10), 2213-2220. 
Nikfarjam, A., \& Zarifi, S. (2015). Exploring the effects of entrepreneurial marketing factors on SMEs. Uncertain Supply Chain Management, 3(4), 333-338.

Nikseresht, F. (2013). How empowering small and mid-cap firms develops national exports. Management Science Letters, 3(10), 2661-2664.

Nosouzi, H., Azad, N., \& Naami, A. (2013). An empirical investigation on factors influencing on exporting medicinal plants. Management Science Letters,3(6), 1539-1546.

Shekari, H., Shirazi, S., Afshari, M., \& Veyseh, S. (2011). Analyzing the key factors affecting the green supply chain management: A case study of steel industry. Management Science Letters, 1(4), 541550.

Wolff, J. A., \& Pett, T. L. (2000). Internationalization of small firms: An examination of export. Journal of Small Business Management, 38(2 s 34). 